\title{
Rational microeconomic management and its non-optimal macroeconomic outcomes: the role of social institutions
}

\author{
Adam Koronowski ${ }^{1 \text { a }}$ \\ “Cardinal Stefan Wyszynski University, Warszawa, Poland
}

(C) 2019 Adam Koronowski. This is an open access article distributed under the Creative Commons AttributionNonCommercial-NoDerivs license (http://creativecommons.org/licenses/by-nc-nd/3.0/

DOI 10.2478/WSBJBF-2019-0015

\begin{abstract}
The paper analyzes possible policy and institutional responses to underconsumption, which is viewed as an effect of a specific market failure. Microeconomic rational decisions to keep labor costs low, resulting in suboptimal macroeconomic outcomes. Traditionally, constraints arising out of deficient demand have been corrected with expansionary fiscal and monetary policies. These methods have ceased to be effective and viable. Alternative measures should be targeted at changing income distribution; low labor income is the reason for underconsumption. Such measures (progressive income tax, stronger labor unions) would probably not gain any acceptance of entrepreneurs, even though, in principle, they should boost business activity. Non-confrontational solutions are beyond the reach of economic policy but an informed democratic debate might lead to a desirable compromise.
\end{abstract}

\section{Introduction}

There are different views on the outcomes of the uninterrupted functioning of the market. Extreme views could be related to the notion of efficient markets and the idea of market failures. In contemporary economics, there is little room for a clear laisse-faire attitude, which is mirrored in the belief of self-regulating and optimizing markets. As a consequence, the question of proper framing of markets with regulations, institutions and policies that ameliorate their functioning is central to economic debate.

The answer to the question of intervention depends on the character of the identified market failure. Market failures may happened because of several reasons, such as time inconsistency, information asymmetry, bounded rationality, transaction costs, noncompetitive markets, principal--agent problems, externalities and public goods. Each of these reasons is a broad category, and specific theories can explain each of them. Numerous tools, which are extremely differentiated and often disputable, are available to correct market failures. A general problem related to such corrective measures is their effectiveness. In particular, it may be subject to skepticism or open criticism, and often regarded as a government failure. It is also considered to be a disability of governments or public organizations to make things better rather than worse. Different opinions about this problem assume very specific forms depending upon the individual issues that are in focus. An example might be endless, and very current in these days, debates concerning regulation versus liberalization of financial markets.

The problems become even more complicated when one turns to macroeconomic policy. Contemporary economists rarely claim that unfettered markets tend towards a stable, full-employment equilibrium. The idea of macroeconomic policies that actively seek to mitigate economic fluctuations and to protect employment and

\footnotetext{
1 a.koronowski@uksw.edu.pl
} 
business activities is broadly accepted. Of course, this is far from the view that macroeconomic policies always yield positive results or that they themselves cannot cause any disturbances.

In this paper, a specific form of market failure is considered - underconsumption due to low labor incomes. Its effects are manifested as macroeconomic business fluctuations or recessionary tendencies. Optimizing, wellinformed, rational decisions made by business managers bring about nonoptimal macroeconomic, social results, but eventually they also result in inferior outcomes for individual agents themselves. There is a lack of socially optimal coordination of microeconomic decisions. Respectively, there should be room for corrective institutional measures and policy decisions. The aim of the paper is to answer a question whether some nonconfrontational changes in social institutions framing the market are conceivable to offset market fluctuations.

The next part of the paper presents an analysis of the theoretical problem of managerial, microeconomic attitudes towards wage costs and their possible negative outcome in the form of underconsumption and stagnation, leading to high unemployment. In the third part of the paper, some possible corrective measures are considered, and in the fourth part, the chances of their acceptance by business are discussed. The last part of the paper provides conclusions.

\section{Non-optimal macro and microeconomic results of rational managerial decisions}

Kalecki [1935] says, "What is good for an individual entrepreneur is possibly not good for all entrepreneurs as a group." This statement puts the idea of socially inferior outcomes of rational, microeconomic decisions in a nutshell. Kalecki refers this possibility to underconsumption, i.e. to a situation when low consumption spending financed from low-wage incomes does not support new investment undertaken with the aim to augment production possibilities. Eventually, all private spending is low, and there is a general problem of deficient demand and savings surplus. This leads to a fall in production and employment; recession and stagnation succeed. In Kalecki's words, "if one entrepreneur cuts wages, he could, ceteris paribus, increase the utilization of his factory, but if all entrepreneurs cut wages the result (...) would be quite different." They would find it impossible to sell their products.

The idea of deficient consumption demand that limits investment, aggregate demand, production and employment is not quite firmly established in economics. It is still rather a hypothesis of underconsumption. However, it has been a long tradition in the history of economic thought. Of course, it is more of a general attitude which accepts that economy may be subject to demand constraint. The specific and very precise idea of underconsumption is older than the more general and vague Keynesian theory of deficient demand. A broad discussion of the hypothesis of underconsumption clearly goes beyond the scope of this paper. However, it is worth emphasizing that the hypothesis is being rediscovered in contemporary, post-crisis economics as a theoretical paradigm providing a good basis for interpreting contemporary economic developments [Wilcock, Scholz, 2016].

As Kalecki says earlier, underconsumption is a case of a socially inferior outcome of rational microeconomic decisions. It is difficult to say that the decisions are coordinated; they are rather based on the same premises. Moreover, the decision to cut wages (wage costs) is rational (except in the very tight labor market or as a motivating function of wages) from the managerial point of view, irrespective of what other entrepreneurs do in this respect. However, if these individual decisions could be changed in a coordinated way, the result would be better.

No firm invests more than is necessary to preserve the potential to meet the demand for its products generated using a given technique, which relates the product to capital inputs. If wages are cut, the share of labor income and consumption in GDP is also diminished. It does not provide justification for high investment (in the consumption goods sector and, respectively, in the investment goods sector). Production and capital income eventually fall too. Economy shrinks, and employment drops in particular.

It is a fall in real wages that is important; it causes real economic contraction. It is a matter of debate whether prices could revert this negative mechanism and fall in line with nominal wages. This is an old problem that was analyzed, among others, in the paper by Kalecki [1935], and then it was deeply considered by Baran and Sweezy [1968]. Shortly speaking, in contemporary economics, it is commonly claimed that prices are sticky. Moreover, as underlined by Kalecki, if an economy faces the problem of underconsumption due to low wages, a decline in both prices and wages does not solve the problem. When only wages fall, the problem aggravates. The only solution would be falling prices and profits at fixed wages; this process restores the shares of labor income and consumption that are consistent with macroeconomic equilibrium (not necessarily full-employment equilibrium; it may be lessthan-full-employment, "Keynesian" equilibrium if the volume of consumption does not justify full utilization of production capacities and does not support new investment).

In the framework sketched above, wage cuts bring about economic contraction; an increase in wages should respectively make economy unwind, leading to a growth in employment in particular. Of course, to raise wages is in sharp contradiction to microeconomic rationality, and it cannot happen unless some institutional corrective mechanism is in place. 


\section{Activist policy against economic slumps}

In contemporary mainstream economics, the problems of business cycle fluctuations and recessionary tendencies are to be solved by fiscal or monetary measures. The manifestations of fluctuations (high unemployment in particular) are subject to activist policy interventions, but causes of fluctuations are not addressed and not even properly recognized. Typically, Keynes in his general theory of interest, money and unemployment claims that investors exhibit "animal spirits" and that the resulting economic slumps might be cured with fiscal intervention. Of course, the idea of "animal spirits" is a simple version of nonoptimal coordination. Since such behavior allegedly lacks any underlying regular mechanism, it cannot be systematically and scientifically analyzed or addressed. In this case, policymakers can only diminish its negative results in the form of depressed economic activity.

If there are persistent tendencies toward stagnation due to underconsumption, expansionary fiscal and monetary policies tend to be on average biased toward an expansionary stance. This has been the case in recent decades. With respect to fiscal policy, it is reflected in ever-growing public debts in the developed world. When it comes to monetary policy, even when it is effective in stabilizing prices, it still is conducive to excessive growth of private debt (financialization, "privatized Keynesianism" [Crouch, 2009]). It also fuels speculative bubbles and generally fails to boost sustainable economic growth. Easy monetary policy is charged with creating conditions for financial (and economic) instability ([White, 2006, 2006a], [Koronowski, 2009], [Koronowski, Ryan, 2009]). Both fiscal and monetary policies seek to improve the economic situation but they are not targeted at the deep reasons for the problems they address, and they only try to affect the outcomes. They eventually fail and,in the meantime, they cause negative side effects and create new imbalance and tension. Alternative policies and institutions are necessary to solve the problem of underconsumption.

In line with the hypothesis of underconsumption, one may argue that low aggregate demand is a result of low consumption or low labor income. When this mechanism is recognized, the efforts to revert recessionary tendencies should be made addressing the reasons that caused demand to fall and should not manifest as economic slumps.

High wages could not be a supply-side barrier to more production. If we think about this problem in the categories of shares/proportions (and volumes) of income consistent with (full-employment) equilibrium, we may easily claim that wages may be too high or too low. In the first case, accumulation is much restricted, and it does not supply financial resources that could be reasonably invested. In the latter case, accumulation is excessive with respect to profitable investment opportunities. In this article I take the perspective of a low share of labor income. Falling shares of labor income is a well-established statistical fact in modern economy, which seem to be the reason for underconsumption and tendencies toward stagnation ([Stiglitz, 2012], [Piketty, 2014], [OECD, 2012], [ILO, OECD, 2015]). The present economic problems may be in part an effect of supply-side policies of the 1980s, such as the reduction of the role of labor unions. Of course, labor unions were not intended as a mediator to correct macroeconomic effects of wage setting, but eventually they could play this role. If economists understand these effects brought about by this specific institution, they can change their attitudes toward labor unions. Creating or dismantling economic institutions obviously needs good theories that correctly describe and explain economy; this statement should be valid even when we agree that any economic theory cannot provide one-directional recommendations that are correct irrespective of a specific situation.

Economics is far from giving a clear advice whether economies are wage-led or profit-led; there are, however, up-to-date analyses that document a negative impact of higher income inequality on economic growth and stability ([Berg, Ostry, 2011], [Berg, Ostry, Tsangarides, 2014], [Dabla-Norris et al., 2015], [Diallo et al., 2011]). As one accepts the notion that equilibrium is a matter of proportions, there is no single, universal and correct answer. It means that sustainable economic growth depends on a balance that may be shaped by institutional settings and policies.

In these days, the balance is distorted at the expense of labor income. Changes in the income structure observed in recent decades arise from a few reasons. Without doubt, they are a result of globalization and technological progress [Koronowski, 2016]. However, the institutional balance in the contemporary economy has also shifted in a way that bolsters the process of shrinking the share of labor income. Labor unions have lost much of their power to influence wage negotiations. Labor is often subject to higher income tax than capital. Many corporations are stuffed with money, but they do not invest (or they invest in existing assets in a way that leads to speculative bubbles) ([Dembinski, 2011], [Foster, McChesney, 2014]). The trend should be reverted.

A corrective mechanism could take different forms. First, since the discussed problem is rooted in income distribution and specific spending patterns typical of different income categories, it can be addressed with redistributive policies. A progressive income tax is the most typical tool in this respect. Another solution to the same problem is suggested by Malthus and Kirchman who argue for high, conspicuous consumption financed from capital income and thus lower savings that try to find outlets in excessive accumulation and production capacities above the demand constraint [Dziewulski, 1989]. Income redistribution as a means to solve the problem of underconsumption is an old idea, which was proposed as early as the beginning of the $19^{\text {th }}$ century by Sismondi and Rodbertus. Income redistribution through progressive income taxes as a solution to the problem of 
underconsumption was proposed by Hobson at the end of the $19^{\text {th }}$ century [Richmond, 1978]. The same proposal of progressive income tax has been recently made by Piketty [2014]. His claims, however, do not refer directly to underconsumption but to the author's pretentious "laws of capitalism," which are statistical tautology and a vague and controversial hypothesis [Koronowski, 2018].

In the practice of fiscal policy, progressive income taxes were traditionally justified rather with socio-political than economic arguments. Economic arguments used to be mostly in the spirit of supply-side economics, and they pointed to the need for cutting higher tax rates applied to higher income; in the recent decades, these arguments have been winning [Stiglitz, 2012]. If we recognize the problem of underconsumption, these arguments are false or outdated.

It is necessary to make a reservation here; if an economy is in low-employment equilibrium, the problem of deficient demand is no longer related to labor and capital income shares but to low levels of all income. Even when the initial reason for stagnation is underconsumption, eventually all types of income fall. At this stage, a redistribution of income via taxation would probably not suffice. An extra incentive might be necessary, in particular in the form of increased public spending. However, this should be only a kick-off and not a permanent dragging of the stagnating economy with fiscal expansion. Without wage increase, underconsumption would quickly stuff out any pickup of the economy.

Another mechanism that can play a similar role may be the increased power of wage bargaining due to stronger labor unions. Supply-side economics argues for dismantling this mechanism. However again, if economies stagnate because of deficient demand (underconsumption), this recommendation is counter-productive.

\section{Is non-confrontational solution possible?}

Rational wage decisions made by managers supposedly bring about neither a social, macroeconomic optimum, nor optimal results for individual firms. Corrective institutional and policy measures could also improve business prospects. However, a question arises whether managers are able to recognize and accept the need for institutions and policies that modify the effects of their decisions. Possibly, managers may manifest their bounded rationality in the sense that they are well-informed and rational within the scope of their typical, individual, microeconomic decisions, but they may not recognize the macroeconomic results. Whatever is beyond the scope of their individual decisions may fall into a dark area of constrained cognitive abilities of managers. A coordinative action and information campaign could help to solve the problem in a manner accepted by business managers. It is also possible that despite the lack of optimal coordination, any forced solution may be rationally rebuffed by business people.

Any attempts to set corrective measures that influence income distribution may face a strong resistance. In particular, they would violate a well-established view of "proper" business-friendly regulations and policies and the respective system of power and interests. Typically, managers and capital owners would claim that any analysis of the income structure is purely ideological and lacks economic background, although mainstream economics supported this attitude until recently. Lucas [2004] claims that income distribution does not belong to professional economics. However, business people also argue that wage increase will be harmful to economy, which is inconsistent. At the corporate level, rational interests to keep wages low allegedly backed by economic theory and a lack of reasonable, alternative, coordinated and non-confrontational solutions all create strong barriers for business to consider income redistribution (higher labor incomes), which might eventually bring about higher income in general.

However, the attitudes of business people to resist any attempts to establish public institutions and policies of income redistribution may still be rational. First, some managers may be afraid that the impact of a general wage increase on their businesses could be discriminatorily negative. This would be the case of labor-intensive industries. Income demand elasticities also matter. Second, business people might reluctantly let the balance of power shift towards labor (or government). Power may be highly appreciated; a shift may also create risks of an excessive wage increase, denting profits that could be reasonably invested, in the future. Third, in an open economy, rising labor costs make domestic firms less internationally competitive, which has negative sectoral and macroeconomic consequences. In principle, the last reservation can be lifted with respect to the macroeconomic impact if a flexible exchange rate allows for adjustment needed.

The case of income redistribution through the progressive income tax is different. Most arguments that relate to the wage increase are not applicable. Anyway, it may be difficult to grasp the idea that if profits remain little taxed, their net amount earned may be lower.

The idea can be explained with a simple, model example: let the equilibrium wages equal two-thirds of GDP (so profits and investment equal half of consumption demand), in low-employment equilibrium wages equal 2 and profits 1. Due to an incentive, economy starts growing; wages equal 3 and profits rise to 3 . Now the new proportion of labor and capital incomes leads to underconsumption. Eventually profits cannot be realized, and they settle at half of consumption demand and equal 1.5. However, if income tax would leave net profits equaling 2 (out of 3 
before taxes) and the tax proceeds would be spent as (public) consumption, proportions that guarantee equilibrium would be preserved at wages (private consumption) equaling 3 , profits equaling 2 and public consumption equaling 1. There is no public deficit. In principle, the mechanism is the same as the balanced budget multiplier.

Anyway, higher taxes always are met with reluctance; it may be against well-established intuition that it is better not to dispose of one's own money easily, even in a coordinated manner. Another difficulty may be international tax competition. Last but not the least, in the same way as in the case of wage increase, business people may rationally fight to avoid a situation when a shift in institutional balance is excessive and profits after taxes are dented so that even new investment is impaired.

In spite of the skepticism expressed above with regard to the acceptance of the corrective measures discussed here, there is evidence that some institutions and activist policies win business acceptance; entrepreneurs are not against state intervention in principle. This is the case of Keynesian-type, expansionary fiscal policy, which is not opposed by entrepreneurs, managers or capital owners. This was noticed and explained by Baran and Sweezy [1968]. Fiscal expansion and budget deficits do not impair profits after taxes; they boost demand, and they let interested parties invest financial "surplus" with profit in government bonds. This policy does not refer to underconsumption and income distribution, which is precisely in line with the interests of capital owners and it is business friendly. This is probably the main reason for its popularity in recent decades. The trouble is that it has the negative side effects mentioned and, along with easy monetary policy, it has ceased to be a viable solution to the problem of deficient demand.

\section{Conclusion}

Even when individual, non-coordinated microeconomic rationality stays at odds with macroeconomic optimization, it may be very difficult to gain acceptance for corrective measures. A refusal of such measures by business people may arise from arguments that rational at the microlevel, even though there is room for improved social outcomes and individual financial effects. The target function of a firm may be compound, and managers may take into consideration time inconsistency and the system of economic power. Individual impact of corrective measures may also depend on a particular situation of each firm, and it would be impossible to assess it ex-ante. It may be difficult to establish proper, efficient and non-confrontational institutions that seek to erase the conflict between microeconomic, non-coordinated rationality and macroeconomic optimization expressed as underconsumption and that would substitute for worn out expansionary fiscal and monetary policies.

Anyway, a difficult task to design and to implement proper policies and institutions needs some good economic theory in the first place. In particular, it is important to identify and to understand situations in which microeconomic decisions are inconsistent with macroeconomic, social optimization. It would be naïve to believe that decisions and opinions of managers should lead economic thinking; on the contrary, it is the theory that must explain the functioning of economy and provide guidance. When proper guidance is in place, it may shape public debate and policies that constitute and arise from the democratic process based on a compromise. When such democratic compromise does not emerge and interests and resistance to the change presented by privileged groups take a lead, there is a risk of economic and political instability.

\section{References}

Baran P. A., P. M. Sweezy (1968), Monopoly Capital, an Essay on the American Economic and Social Order, Modern Reader Paperbacks, New York, London

Berg A.G., J. D. Ostry (2011), Inequality and Unsustainable Growth: Two Sides of the Same Coin?, IMF Staff Discussion Note, April 2011

Berg A., J.D. Ostry, C. G. Tsangarides (2014), Redistribution, Inequality, and Growth, IMF Staff Discussion Note, April 2014

Dabla-Norris, E., Kochhar, K., Suphaphiphat, N., Ricka, F., Tsounta, E. (2015), Causes and Consequences of Income Inequality : A Global Perspective, IMF Staff Discussion Notes No. 15/13

Diallo M. B., P. Flaschel, H.-M. Krolzig, C. R. Proano (2011), Reconsidering the Dynamic Interaction Between Real Wages and Macroeconomic Activity, Research in World Economy 2, no. 1, April 2011

Crouch C. (2009), Privatized Keynesianism: An Unacknowledged Policy Regime, The British Journal of Politics \& International Relations, Volume 11, Issue 3, August 2009, http://onlinelibrary.wiley.com/doi/10.1111/j.1467-856X.2009.00377.x/abstract (access 20.11.2017)

Dembiński P. H. (2011), Finanse po zawale, Wydawnictwo Studio Emka, Warszawa

Dziewulski J. (1989), Teoria ekonomiczna Róży Luksemburg, PWN, Warszawa

Foster J. B., R.W. McChesney (2014]) Kryzys bez końca, Instytut Wydawniczy Książka i Prasa, Warszawa

ILO, OECD (2015), The Labour Share in G20 Economies, Report prepared for the G20 Employment Working Group (Turkey, 26-27 February 2015), https://www.oecd.org/g20/topics/employment-and-social-policy/TheLabour-Share-in-G20-Economies.pdf (access 27.05.2018) 
Kalecki M. (1935), Istota poprawy koniunkturalnej, reprinted in: Kalecki M., Kapitalizm: dynamika gospodarcza i petne zatrudnienie, wybór tekstów pod red. K. Łaskiego i J. Osiatyńskiego, iTON Society, Warszawa

Koronowski A. (2009), Polityka pieniężna a kryzysy finansowe, Gospodarka Narodowa, no. 10/2009

Koronowski A., J. Ryan (2009), Greenspan's Legacy and Bernanke's Attitude to Financial Crisis, Working Paper no 19/WP/2009, Department of Economics, Ca' Foscari University of Venice

Koronowski A. (2016), Technological Progress and Unemployment; Luddism and Beyond, Gospodarka Narodowa, no. $4 / 2016$

Koronowski A. (2018), Czy niski udziat plac w PKB prowadzi do stagnacji?; hipoteza niedostatecznego popytu konsumpcyjnego, Gospodarka Narodowa, forthcoming

Lucas R. E. Jr. (2004), The Industrial Revolution: Past and Future, 2003 Annual Report Essay, The Federal Reserve Bank of Minneapolis

OECD (2012), Labour Loosing to Capital: What Explains the Declining Labour Share?, OECD Employment Outlook 2012

Piketty T. (2014), Capital in the Twenty-First Century, Cambridge, MA, Belknap Press

Richmond W.H. (1978), John A. Hobson: Economic Heretic, The American Journal of Economics and Sociology Vol. 37, No. 3 (Jul., 1978)

Stiglitz J. (2012), The Price of Inequality, W.W. Norton \& Co., Inc.

White W.R. (2006), Is price stability enough? BIS Working Paper no. 205

White W.R. (2006a), Procyclicality in the financial system: do we need a new macrofinancial stabilization framework? BIS Working Paper no. 193

Wilcock N., Scholz C. (2016), An Underconsumption Crisis, In: Hartmut Elsenhans and a Critique of Capitalism. Palgrave Macmillan, London 